Miloš Petrović*

Univerzitet u Nišu, Građevinsko-arhitektonski fakultet, Niš, Srbija

Scientific paper

ISSN 0351-9465, E-ISSN 2466-2585

UDC:504.75:054.064.001.672

doi:10.5937/ZasMat1701037P

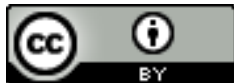

Zastita Materijala 58 (1)

$37-40(2017$

\title{
A simple numerical model for monitoring the quantity of carbon monoxide in the air caused by the traffic pollution
}

\begin{abstract}
Investigation of the quality of air includes a series of specific emission and immision measurements of pollutants and it is regulated by domestic and foreign laws. The urban traffic is considered one of the emitters of noxious matters in the air. The emission of exhaust gases from the internal combustion engines is the source of numerous pollutants: burned or partially burned hydrocarbon, carbon monoxide, nitrogen oxides, soot, etc. The paper presents a numerical model that enables prevention of carbon monoxide concentration in the air based on air parameters measured through forming algebraic polynomials by the least-squares method. The measurement of parameters was performed in the Republic Institute of Public Health, at the location near the National Theatre in the Mediana Municipality, the City of Niš. The numerical model was realized in the symbolic system of Mathematica. Based on the formed model, numerical results are given related to the monitoring of carbon monoxide in the air caused by the traffic pollution.
\end{abstract}

Keywords: air pollution, approximation, carbon monoxide.

\section{1: INTRODUCTION}

The combustion process is a chemical-physical process in which the chemical energy bonded in fuel gets transformed under the influence of high temperature. In chemical terms, combustion is oxidation, bonding of all fuel elements with oxygen, which is a tumultuous and fast process itself. The combustible elements of gaseous fuels are mainly hydrogen, carbon monoxide and hydrocarbons. The non-combustible elements of gaseous fuels are carbon dioxide, nitrogen and oxygen. Carbon monoxide is a highly toxic colorless, odorless and tasteless gas and it is lighter than air. It belongs to the group of chemical choking gases and it causes general hypoxia due to irreversible bonding with hemoglobin $(\mathrm{Hb})$. The toxic $\mathrm{CO}$ effect develops quickly in small concentrations[1]. Carbon monoxide occurs in the process of incomplete oxidation of organic matter.

\footnotetext{
${ }^{*}$ Corresponding author: Miloš Petrović

E-mail: petmil@ni.ac.rs

Paper received: 12. 03. 2016.

Paper revised: 23. 04. 2016.

Paper accepted: 15. 05. 2016.

Paper is available on the website:

www.idk.org.rs/journal
}

The exhaust gas from the internal combustion engines is one of the most significant air pollution sources where its quantity may range from 1-14 vol $\%$, while the metal industry is the next great air polluter. In the USA, exhaust gases from motor cars and other internal combustion engines make $58 \%$ of the total $\mathrm{CO}$ quantity emitted in the atmosphere. More than $50 \%$ of all fatal poisonings were caused by $\mathrm{CO}$. Carbon monoxide is inhaled into and eliminated from the organism through lungs, while the ultimate toxic effect reflects in hypoxia caused by the formation of carbonyl compounds which inhibit oxygen $\left(\mathrm{O}_{2}\right)$ binding or its transport, delivery and utilization in the body tissues and cells. The binding of $\mathrm{CO}$ to $\mathrm{Hb}$ is somewhat slower than the $\mathrm{O}_{2}$ binding, but the affinity between $\mathrm{Hb}$ and $\mathrm{CO}$ is $210-240$ times stronger than the affinity between $\mathrm{Hb}$ and $\mathrm{O}_{2}$ [2]. Therefore, $\mathrm{CO}$ has the advantage in binding to hemoglobin even if it is present in too small quantities compared to oxygen. The toxic effect of $\mathrm{CO}$ on the body also depends on the exposure duration and emphasizing factors, i.e. on respiratory minute volume, muscle output, individual resistance of each person, concentration of $\mathrm{CO}$ and intensity of hypoxia. The lethal dose for 
humans is $1000-2000 \mathrm{ppm}(0.1-0.2 \%)$ within the exposure of 30 minutes. With high $\mathrm{CO}$ concentrations in the inhaled air, 1-2 minutes of exposure may lead to death. Maximum allowed concentration (MAC) in industry amounts to 50 ppm $(0.005 \%)$ within 8 hours of exposure, while the scuba-diving compressed air can contain $10 \mathrm{ppm}$ $(0.001 \%)$ at the most. The clinical picture of the poisoning is untypical. Nitrogen oxides emitted in the atmosphere in the combustion process are the pollutants that destroy the stratospheric ozone, increase the intensity of UV radiation, influence global climate changes, produce acid rains and photochemical smog. Formation of nitrogen oxides in burning of fossil fuels is a very complex process affected by chemism, fuel, thermal-mass exchange, as well as by the flow characteristics. Nitrogen oxides represent major polluting matters. Solid fuel appliances emit large quantities of nitrose (nitrogen) oxides. Formaldehyde is the simplest aldehyde. It is produced industrially by the hydrogenization of methanol. Its molecular formula is $\mathrm{HCHO}$. The extensive effect on the environment is connected to human activities and unrestrained exploitation of natural resources [3].

\section{FORMATION OF ALGEBRAIC POLYNOMIALS BY THE LEAST-SQUARES METHOD (FOR A DISCRETE CASE)}

Let $\mathrm{f}$ be a function defined on the discrete set of points $X_{0}, X_{1}, \ldots, X_{n}$ and let the approximated function for $n \geq m$ be $\varphi\left(x, a_{0}, a_{1}, \ldots a_{m}\right)$. The function $\varphi$ is determined from the condition that the sum of squared difference between the function and the approximated function in nodes is minimal [4]:

$$
S=\sum_{k=0}^{n}\left(f\left(x_{k}\right)-\varphi\left(x_{k}\right)\right)^{2} \rightarrow \min
$$

The function $S$ is interpreted as a function of unknown parameters $S=S\left(a_{0}, a_{1}, \ldots a_{m}\right)$. Since $S \geq 0$, regardless of parameters, the problem is reduced to the minimization of the function $S$ as a function with several variables $a_{0}, a_{1}, \ldots a_{m}$.

From the conditions of extreme $\partial S / \partial a_{k}=0$, $k=0,1, \ldots m$ and the approximated function of the form of [5]:

$$
\varphi_{(x)}=a_{0} \varphi_{0}(x)+a_{1} \varphi_{1}(x)+\cdots+a_{m} \varphi_{m}(x)
$$

we obtain:

$$
S=\sum_{k=0}^{n}\left(f\left(x_{k}\right)-\sum_{i=0}^{m} a_{i} \varphi_{i}\left(x_{k}\right)\right)^{2} \Rightarrow \frac{\partial S}{\partial a_{j}}=\sum_{k=0}^{n}\left(f\left(x_{k}\right)-\sum_{i=0}^{m} a_{i} \varphi_{i}\left(x_{k}\right)\right)\left(\varphi_{i}\left(x_{k}\right)=0\right.
$$

The most important approximation is the approximation by algebraic polynomials, where space orthogonalization is carried out by some orthogonalization procedure (Graham-Schmidt procedure), in which the following system of algebraic equations is obtained for the discrete case:

$$
\begin{aligned}
& a_{0}\left(\varphi_{0}, \varphi_{0}\right)+a_{1}\left(\varphi_{1}, \varphi_{0}\right)+\cdots+a_{m}\left(\varphi_{m}, \varphi_{0}\right)=\left(f, \varphi_{0}\right) \\
& a_{0}\left(\varphi_{0}, \varphi_{1}\right)+a_{1}\left(\varphi_{1}, \varphi_{1}\right)+\cdots+a_{m}\left(\varphi_{m}, \varphi_{1}\right)=\left(f, \varphi_{1}\right) \\
& \vdots \\
& a_{0}\left(\varphi_{0}, \varphi_{m}\right)+a_{1}\left(\varphi_{1}, \varphi_{m}\right)+\cdots+a_{m}\left(\varphi_{m}, \varphi_{m}\right)=\left(f, \varphi_{m}\right)
\end{aligned}
$$

where for the functions $g$ and $h$ we have

$$
(g, h)=\sum_{k=0}^{n} g\left(x_{k}\right) h\left(x_{k}\right) \text {. }
$$

The error in the nodes to be minimized is

$$
\begin{gathered}
S=S\left(a_{0}, a_{1}, \ldots, a_{m}\right) \\
\rightarrow \text { min }
\end{gathered}
$$

The realization of this model in the Mathematica programming system starts with the definition of data as arranged triplets of digits [6]. 


\section{IMPLEMENTATION IN THE EXAMPLE OF} CARBON MONOXIDE APPROXIMATION

The measurements of exhaust gases from motor vehicles in the Municipality of Mediana made Table 1. Approximation carbon monoxide Tabela 1. Prikaz količine ugljen moniksida

\begin{tabular}{|c|c|c|c|c|c|c|}
\hline \multicolumn{1}{|c|}{ Number } & Period & $\begin{array}{c}\text { Nitrogen } \\
\text { oxide } \\
\text { Nox }\end{array}$ & $\begin{array}{c}\text { Formaldexy } \\
\text { de HCHO }\end{array}$ & $\begin{array}{c}\text { Carbon } \\
\text { monoxide } \\
\text { CO } \\
\text { measured }\end{array}$ & $\begin{array}{c}\text { Carbon monoxide } \\
\text { CO } \\
\text { approximated }\end{array}$ & difference \\
\hline 1 & June & 13.500 & 6.600 & 0.900 & 0.93 & 0.03 \\
\hline 2 & July & 13.700 & 6.600 & 4.100 & 4.13 & 0.03 \\
\hline 3 & August & 5.200 & 6.600 & 3.600 & 3.61 & 0.01 \\
\hline
\end{tabular}

Graphic representation of the results from Table 1. is shown in the chart Figure 1.

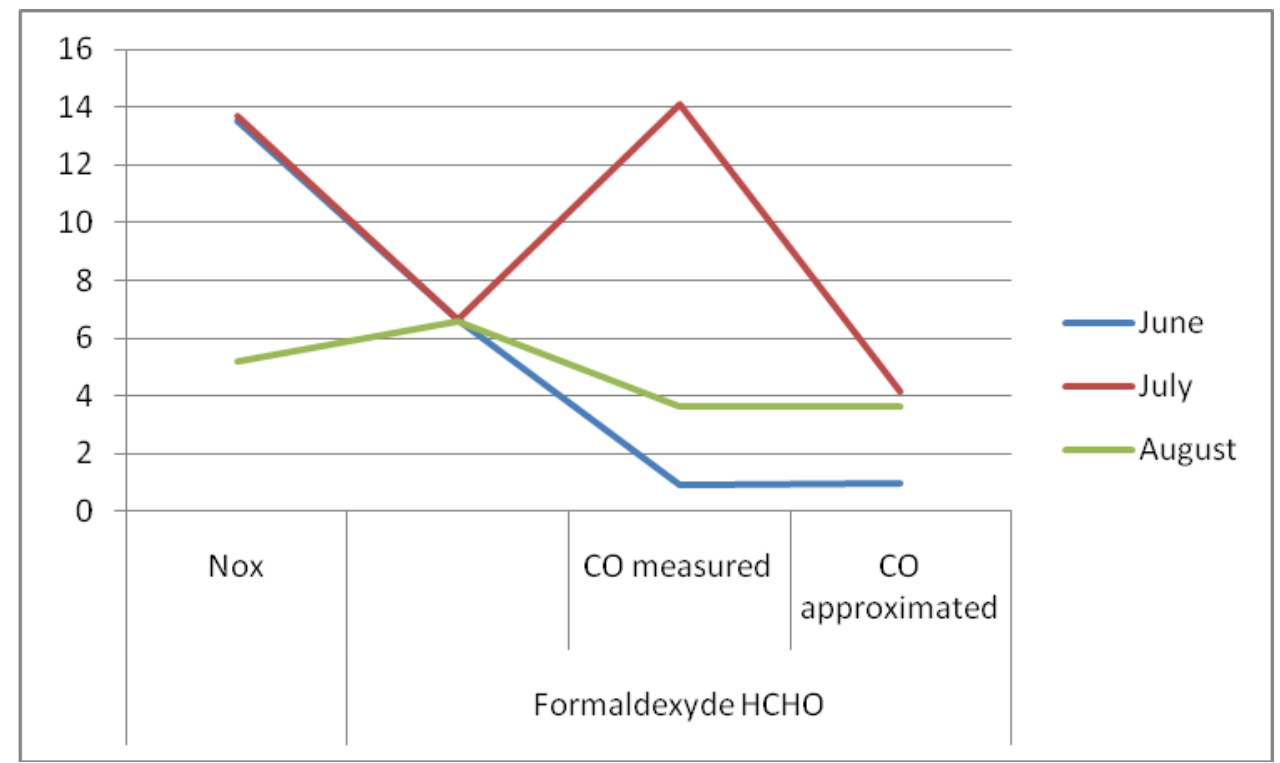

Figure 1. Graphical illustration of approximation carbon monoxide

Slika 1. Grafička ilustracija kolicine ugljen-monoksida

The above explained procedure in the Mathematica system was applied, with a tabular presentation of the results, Table 2. [7].

Table 2. Standard errors and confidence intervals for each coefficient separately

Tabela 2. Standardne greške $i$ intervali poverenja za svaki koeficijent posebno

\begin{tabular}{|c|c|c|c|c|}
\hline \multirow{2}{*}{ Parameter } & \multirow{2}{*}{ Estimate } & \multirow{2}{*}{ Std. Error } & \multicolumn{2}{|c|}{$95 \%$ Confidence Interval } \\
\cline { 3 - 5 } & & & Lower Bound & Upper Bound \\
\hline b0 &, 050 &, 218 & $-2,719$ & 2,819 \\
b1 & 1,000 &, 316 & $-3,018$ & 5,018 \\
b2 & 2,000 &, 316 & $-2,018$ & 6,018 \\
b3 & $-3,000$ &, 447 & $-8,682$ & 2,682 \\
\hline
\end{tabular}


Dependence forms:

$$
z=b 0+b 1^{*} x+b 2^{*} y+b 3^{*} x^{*} y .
$$

The method of nonlinear regression:

$$
z=0.05+x+2 y-3 x y
$$

\section{CONCLUSION}

The applied model shows that it is possible to predict amounts of carbon monoxide in the air on the basis of other measured parameters. Since these measurements are precise, the least-squares method yields well fitted approximation functions, as may be seen in the Table, where the error is reduced. The application of such numerical methods is reasonable in cases where measuring costs should be reduced and where it is necessary to obtain needed data with sufficient accuracy in a simplified manner.

\section{REFERENCES}

[1] G.Milovanovic (1998) Numerical Analysis, knjiga, Part I-III, University of Niš, Serbian

[2] K.Surla (1998) Aproksimacija funkcija i regresiona analiza, knjiga, University of Novi Sad, Serbian

[3] G.Milovanovic, Đ.Đordjević (2007) Numerical Methods in Computational Engineering, book, University of Niš, Faculty of Civil Engineering and Architecture, Niš,

[4] Web site of the company „Wolfram Research, Inc.“, www.wolfram.com

[5] L.Ružičić, Lj.Kostadinović, J.Bošković, S.Milenković, M.Oljača, K.Gligorević (2012) Trendovi zaštite životne sredine na početku trećeg milenijuma, Zbornik radova prvog naučnog skupa "Zaštita životne sredine", Sremska Kamenica, str. 216.

[6] V.Srebenkoska, E.Fidancevska (2013) Environmental issues in materials science and engineering, Zaštita materijala, 54(2), 169-175.

[7] D.Grozdanic (2003) Numerical methods, knjiga, Akademska misao, Belgrade, Serbian

\section{IZVOD}

\section{JEDNOSTAVNI NUMERIČKI MODEL ZA MONITORING KVALITETA UGLJEN MONOKSIDA U VAZDUHU OD DRUMSKOG SAOBRAĆAJA}

Kvalitet životne sredine, a samim tim i praćenje kvaliteta vazduha kao jednog od najvažnijeg faktora za živi svet sve više je u fokusu interesovanja naučnih krugova. U ovom radu je prikazan jednostavni matematički model kojim je moguće izvršiti predikciju količine ugljen monoksida u vazduhu, na osnovu drugih parametara koji se određuju merenjima. Aproksimacija količine ugljen monoksida ostvarena je formiranjem polinoma različitih stepena, metodom najmanjeg kvadrata $i$ sa minimalnim brojem merenih podataka. Kao reprezentativni, prikazani su rezultati merenja parametara pokazatelja kvaliteta vazduha, u Nišu, opština Medijana kod Narodnog pozorišta. Na osnovu njih je izvršena predikcija ugljen monoksida a approksimirani podaci su upoređeni sa merenim. Matematički model je realizovan u programu Mathematica ${ }^{\circledR}$.

Ključne reči: aproksimacija, numerički model, kvalitet vazduha, ugljen monoksid.

\section{Naučni rad}

Rad primljen: 12. 03. 2016.

Rad revidovan: 23. 04. 2016.

Rad prihvaćen: 15. 05. 2016.

Rad je dostupan na sajtu: www.idk.org.rs/casopis

(C) 2017 Authors. Published by Inženjersko društvo za koroziju. This article is an open access article distributed under the terms and conditions of the Creative Commons Attribution 4.0 International license (https://creativecommons.org/licenses/by/4.0/) 